\title{
THE ROLE OF CAROTID STENOSIS IN A PREDICTION OF PROGNOSIS OF CORONARY ARTERY DISEASE
}

\author{
Savetka Paljoskovska Jordanova ${ }^{1}$, Sasko Kedev ${ }^{1}$, \\ Danica Petkoska Spirova ${ }^{1}$, Lily Stojanovska ${ }^{2}$, Marijan Bosevski ${ }^{1}$ \\ ${ }^{1}$ University Clinic of Cardiology, University of Ss. Cyril and Methodius, Faculty of Medicine Skopje, North Macedonia
${ }^{2}$ College of Medicine and Health Sciences, Al Ain, UAE
}

Corresponding author: Savetka Paljoskovska Jordanova, e-mail: savetka_pj@yahoo.com and Marijan Bosevski, e-mail: marijanbosevski@yahoo.com for the University Clinic of Cardiology, University of Ss. Cyril and Methodius, Faculty of Medicine, Skopje, North Macedonia

\section{ABSTRACT}

Aims: The aim of this paper is to indicate if carotid stenosis is predictive for the prognosis of coronary artery disease.

Method and materials: Our study is a prospective cohort study. 1031 patients with proven coronary artery disease $(\mathrm{CAD})$ were recruited consecutively. Carotid ultrasound was used to assess IMT, plaque, or stenosis. They were followed for 24 months for adverse cardiovascular events. Selected demographic date such as smoking history, dyslipidemia, hypertension, laboratory values, and clinical data (associated diseases and risk) were collected from each patient. Total cardiovascular events and mortality rate were followed up for the study population. The results were collected prospectively and retrospectively. The study was organized as a clinical, cross-sectional study and comparative study.

From the data collected with the clinical research, a file was formed in the statistical program with the help of which the data were statistically analyzed.

From the methods of descriptive statistics, absolute frequencies, percentages, arithmetic mean, median, measures of variability, minimum, maximum, standard deviation and logistic regression models were used.

Result: Of the total number of patients 1026 had arterial hypertension (HTA). Data on hyperlipidemia (HLP) had been reported in 895 patients. 1.023 patients had peripheral artery disease (PAB). 1031 patients were presented with multivessel coronary artery disease (CAD). There were 1,029 patients with diabetes mellitus (DM), while 1,013 patients had coronary artery by-pass (CABG), and 1,012 had stroke (CVI). Elevated systolic blood pressure was reported in 966 patients. 184 patients had elevated triglycerides and 187 had elevated cholesterol. 1,008 patients have had a history of myocardial infarction. Carotid artery stenosis (CAS) has been found in 1,009 patients, increased body mass index (BMI) in 270 patients.

1.031 patients were followed for 24 months. Cardiovascular events were reported in 54 patients (or $5.2 \%$ ). Revascularization was performed in $28(4.1 \%)$ patients, while $12(1.8 \%)$ of patients died. Diabetes mellitus (OR 1.878 95\% CI 0.4917 .184 ) and Carotid stenosis (OR 2.185 95\% CI 0.7316 .53 ) were found to be predictive factors for future cardiovascular events.

Conclusion: Due to our results carotid ultrasound may be a useful tool for risk stratification of coronary artery disease pts.

Keywords: Carotid stenosis, coronary artery disease, prognosis 


\section{INTRODUCTION}

It is commonly accepted that a relationship exists between coronary and carotid arterial disease, given that the prevalence of coronary artery disease (CAD) in patients with carotid stenosis is as high as $77 \%$, depending on the population studied [1]. Elevated cardiovascular (CV) risks are apparent in patients with either asymptomatic or symptomatic carotid stenosis. Patients with asymptomatic carotid stenosis are at about a three-fold higher risk of CV death/myocardial infarction compared with a matched population without carotid stenosis, and this risk may be even higher among patients with symptomatic carotid stenosis. Thus, antiplatelet and lipid-lowering therapies have been indicated not only to prevent stroke, but either to lower elevated CV risks. Carotid revascularization has become well established in patients with symptomatic carotid stenosis, which is associated with significant absolute risk reduction in terms of recurrent stroke, however, it remains controversial for patients with significant but asymptomatic carotid stenosis. Carotid revascularization in those with asymptomatic carotid stenosis seems to principally have benefit to patients with specific clinical/imaging features indicating a high risk of stroke. Screening and treatment of asymptomatic CAD can be beneficial for patients with recently symptomatic carotid stenosis and especially for those for whom surgical or endovascular carotid revascularization is planned. Given the lack of beneficial evidence provided by the prophylactic revascularization of asymptomatic carotid artery stenosis in all CABG candidates, at least in terms of reducing perioperative stroke, it may be reasonable to restrict prophylactic carotid revascularization to patients who are at the highest risk of postoperative stroke.

Carotid atherosclerosis is implicated in $20-30 \%$ of the strokes. However, the annual risk of stroke in patients with asymptomatic carotid stenosis is less than 5\%. Symptomatic carotid stenosis poses a greater risk for recurrent stroke with estimates as high as $1 \%$ per year [1]. This paper aims to raise awareness of populations at risk for carotid stenosis, the role of carotid screening and the sensitivity and specificity of various diagnostic modalities. The results of previous trials that support current guidelines for management of symptomatic and asymptomatic carotid stenosis will also be reviewed.
Carotid artery stenosis is defined as narrowing of the common or internal carotid artery in the presence of ipsilateral neurological symptoms referable to the carotid artery if the symptoms occurred less than 6 months prior $(2,3$,$) . Although$ symptomatic carotid artery stenosis is a high-risk factor for recurrent ipsilateral stroke, patients with SCAS are also at an elevated CV risk and CAD is a major cause of death during follow-up in stroke patients.

When treating a patient with significant carotid artery disease, it is important to realize that atherosclerosis is a systemic inflammatory vascular disorder involving multiple arterial beds. These patients are threatened not only by stroke; the presence of carotid artery disease places them into very high-risk group for any of several atherosclerotic cardiovascular (CV) events, especially coronary events. The presence of atherosclerotic disease in more than one arterial system is associated with a higher risk of recurrent symptoms and complications, and patients with detectable disease in the coronary and peripheral arteries are at twice the risk of those presenting with coronary artery disease (CAD) alone.

Although modern pharmacotherapy and revascularization techniques have markedly improved the prognosis of patients with atherosclerotic vascular disease, atherosclerosis-related $\mathrm{CV}$ events and cerebrovascular events remain the causes of death in almost $46 \%$ of all cases in developed countries. Detection and treatment of preclinical CAD in patients with significant carotid artery stenosis may improve long-term outcomes and survival, because CAD is a major cause of death not only during follow-up in stroke patients, but also in patients with asymptomatic carotid stenosis.

According to one meta-analysis, the 5-year risk of stroke in symptomatic patients with 50$69 \%$ carotid stenosis who were treated medically was $27.7 \%$. The 5-year risk of stroke in symptomatic patients with $70-99 \%$ carotid stenosis treated medically was $32.7 \%$ [4,6]. A significant benefit of carotid revascularization in terms of preventing recurrent stroke in patients with symptomatic carotid artery stenosis was confirmed in the meta-analysis. Carotid endarterectomy (CEA) conferred a significant $7.8 \%$ absolute risk reduction for stroke at 5 years in patients with 50-69\% stenosis, and the maximum benefit was observed in patients with 70-99\% stenosis, for whom the absolute risk reduction for stroke was $15.6 \%$; 
equivalent to 156 strokes prevented over 5 years per 1,000 CEAs.

In the early years after a stroke, the most common vascular event is another stroke. However, at 5 years, twice as many deaths are due to myocardial infarction than recurrent stroke. Patients with a history of previous ischemic stroke are at a well-documented risk of myocardial infarction, ranging from $4 \%$ within 3 months of stroke onset to $1 \%$ per year thereafter. However, we need to realize that only $10-12 \%$ of strokes involve acute occlusion or a thromboembolism from a $50-99 \%$ carotid stenosis [5]. Patients with symptomatic carotid stenosis are certainly at a higher risk of myocardial infarction than the general ischemic stroke population. However, the $\mathrm{CV}$ risk of this population is not well documented [6,7]. Considering that patients with carotid artery stenosis develop CAD at almost twice the rate of the overall population of stroke patients, their $\mathrm{CV}$ risk appears to be extremely high [8].

Bosevski [4] has done numerous researches and studies on the importance of carotid ultrasonography, pointing out the importance of determining specific pre-existing parameters of the carotid ultrasound: the presence of carotid age and coronary artery stenosis.

Diagnosis of carotid disease - Doppler ultrasonography is commonly used to diagnose carotid stenosis, to assess cervical artery flow, and to grade the stenosis. With its simplicity, speed and non-invasiveness, Doppler sonography provides accurate information and is a diagnostic method of choice. Its application contributes to the reduction of cardiovascular and cerebrovascular morbidity and mortality.

Early detection and appropriate treatment of carotid artery disease will reduce the consequences of untimely treatment, which includes disability and sometimes even death as a result of stroke caused by carotid artery disease. It is recommended that in the population over 50 years of age, preventive examinations be performed once a year. In patients with proven carotid disease, examinations should be performed according to the doctor's recommendation.

The aim of this paper is to show if carotid stenosis is predictable for the prognosis of coronary artery disease.

\section{METHOD AND MATERIALS}

Our study is a prospective cohort study. 1,031 patients with proven coronary artery disease (CAD) were recruited consecutively with coronary angiography. Carotid ultrasound was used to assess IMT, plaque, or stenosis. Carotid intima-media thickness (CIMT) was measured by B-mode ultrasound using a linear transducer (7.5-10 MHz) and was performed by a single sonographer. CIMT is presented as a mean value of two measurements from both sides of the common carotid arteries. CIMT is defined as the distance from the leading edge of the first echogenic line to the leading edge of the second echogenic line on the scans, with the first line representing the lumen-intima interface and the second line representing the collagen-containing upper layer of the adventitia. Plaque was defined as a localized thickening lesion $(\geq 1.1 \mathrm{~mm})$. Carotid stenosis greater than $60 \%$ was considered significant. In each longitudinal projection, the site with the greatest thickness (including plaques) was detected along the vessel from the common carotid artery to the internal carotid artery [3].

Anthropometric measurements (weight in kilograms (kg) and body mass index (BMI) in $\mathrm{kg}$ $/ \mathrm{m} 2$.) We measured waist and hip circumferences with a plastic meter.

Thickness will be defined as BMI $>30 \mathrm{~kg} /$ $\mathrm{m} 2$. and increased weight as BMI $>25$ and $<29.9$ $\mathrm{kg} / \mathrm{m} 2$. Hyperlipidemia was defined as a value of triglycerides $>/=1.7 \mathrm{mmol} / \mathrm{L}$ ora value of low $\mathrm{HD}<0.9 \mathrm{mmol} / \mathrm{L}$, or as LDL cholesterol $>$ $25, \mathrm{mmol} / \mathrm{L}$. Arterial hypertension was defined as a value of blood pressure higher than $140 \mathrm{mmHg}$ (systolic) and $90 \mathrm{mmHG}$ (diastolic).

They were followed for 24 months for adverse cardiovascular events. Selected demographic data such as smoking history, dyslipidemia, hypertension, laboratory values, and clinical data (associated diseases and risk) were collected from each patient. Total cardiovascular events and mortality rate were followed up for the study population. The results were collected prospectively and retrospectively. The study was organized as a clinical, cross-sectional study and comparative study.

From the data collected with the clinical research, a file was formed in the statistical program with the help of which the data were statistically analyzed (SPSS 20). 
From the methods of descriptive statistics, absolute frequencies, percentages, arithmetic mean, median, measures of variability, minimum, maximum, standard deviation were used.

Significance testing was performed at the level of probability $p<0.05$, which is necessary and sufficient in medical scientific research work to draw relevant conclusions. Logistic regression analysis was built to define predictors of clinical faith.

\section{RESULT}

Out of the total number of patients 968 had familial CAD (Table 1). 1,026 patients had hypertension (HTA). Data on hyperlipidemia (HLP) have been reported in 895 patients. 1,023 have peripheral artery disease (PAB). Carotid disease was recorded in 1,030 patients, while 1,031 patients with multivessel coronary artery disease (CAD). There were 1,029 patients with diabetes mellitus (DM). 1,013 patients had coronary artery by-pass (CABG), and 1,012 had stroke (CVI). Elevated systole has been reported in 966 patients. 184 patients had elevated triglycerides and 187 had elevated cholesterol. $\mathrm{HgA1C}$ was elevated in 144 patients. 1,008 patients had myocardial infarction. 1,009 patients had Carotid Artery Stenosis (CAS).

Family CAD $0.93 \%$, Hypertensio arterialis $0.99 \%$, Hyperlipidemia $0.72 \%$, Obesity $0.34 \%$, Smoker 0.92\%, PAB 0.99\%, Multivessel 1\%, Carotid disease $0.99 \%$, DM 0.99\%, CABG 0.98\%, CVI $0.98 \%$, Systolic blood pressure $0.93 \%$, Triglicerides $0.17 \%$, HgA1C $0.13 \%$, Cholesterol $0.18 \%$, Myocardial infarction $0.97 \%$, Carotid ar- tery stenosis $0.97 \%$, increased body mass index $0.26 \%$

We followed myocardial infarction, brain infarcts and revascularizations, hospitalizations and death. Cardiovascular events were noted in a follow up of 24 months (Table 2 and Figure 1).

1,031 patients were followed for 24 months. Cardiovascular events were reported in 54 patients or $5.2 \%$. Out of the total number of patients $6(0.9 \%)$ had Re CVI. The most common events were Re MI seen in 355 (34.4\%) patients. With 42 patients $(6.2 \%)$ hospitalized. Revascularization was performed in $28(4.1 \%)$ of the total number of patients, and 12 patients died $(1.8 \%)$

Our study found that conventional risk factors such as hypertension, diabetes, smoking, and dyslipidemia are associated with carotid stenosis, and carotid stenosis is indicative of coronary artery disease. A clear indicator of this are the variables entered in the spreadsheet obtained as a result of our research work. Carotid revascularization is a well-established practice and gives good results in all patients with risk factors, especially in writers, patients with stenosis and diabetes mellitus. The following tables show patient mortality. Relevant data on mortality in patients with Obesity, Smoker, PAB, DM, Carotid stenosis, HTA, HLP we present in Table 3 and Table 4.

Patients with carotid stenosis are seen to have a significantly higher risk of death compared with the corresponding population without carotid stenosis. Mortality is high in both obese patients and patients with diabetes mellitus.

Table 1. Relevant clinical data for the patient group

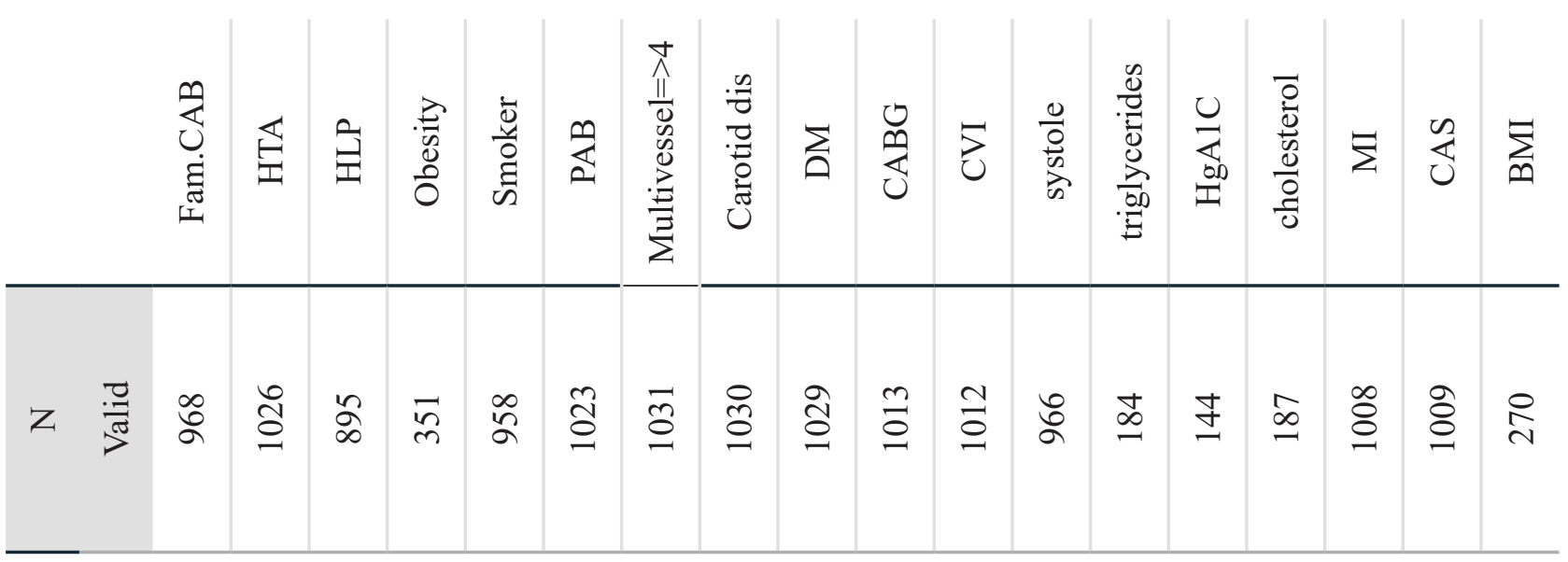


Table 3, which shows the correlation of variables with future events in people with coronary artery disease, shows that the risk is the highest in patients with diabetes and stenosis. Exp (B) in patients with diabetes is 1.5 , and in patients with stenosis $\operatorname{Exp}(B)=4.1$.

Table 4 shows relevant mortality data for patients in regression correlation with obesity, smoker, PAB, DM, carotid stenosis, HTA, HLP. The obtained values shown in the table 4 show that the value of $\operatorname{Exp}(B)$ is the highest in patients with diabetes, obesity and stenosis. Mortality in these patients is the highest. Exp (B) in patients with diabetes is 3.591, $\operatorname{Exp}(\mathrm{B})$ in obese patients is 1.678 , and in patients with stenosis $\operatorname{Exp}(\mathrm{B})=$ 6.027 .

Table 2. Cardiovascular events

\begin{tabular}{|c|c|c|c|c|c|}
\hline 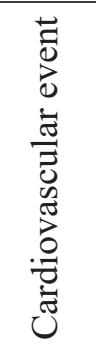 & $\begin{array}{l}\overrightarrow{8} \\
\widetilde{2}\end{array}$ & 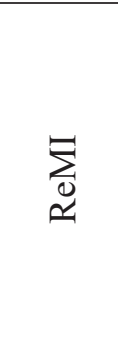 & 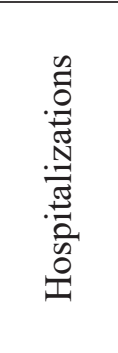 & 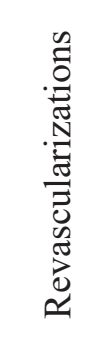 & $\begin{array}{l}\text { 䓌 } \\
\text { ص }\end{array}$ \\
\hline 54 & 6 & 355 & 42 & 28 & 12 \\
\hline $5,2 \%$ & $0,9 \%$ & $355 \%$ & $6,2 \%$ & $4,1 \%$ & $1,8 \%$ \\
\hline
\end{tabular}

\section{DISCUSSION}

Carotid disease is a common finding in patients with coronary artery disease (CAD) and its presence is associated with worse clinical outcomes. Intima-media thickness provides incremental value over traditional risk factors in predicting cardiovascular events; however, it does not predict the absence of CAD or its extent and severity [9]. The presence of carotid plaques is associated with an increased risk of cardiovascular events in patients with CAD regardless of the treatment strategy (medical therapy alone or myocardial revascularization). Hence, we advocate the screening of patients with diagnosed $\mathrm{CAD}$ for carotid atherosclerosis. The prognostic impact of ultrasound characteristics of carotid plaques on cardiovascular outcomes of patients with CAD remains controversial [10].

The coexistence of carotid and coronary artery disease (CAD) is a challenge to cardiologists, vascular and cardiothoracic surgeons as well as neurologists. Patients with coexistent narrowing of carotid and coronary arteries represent a particular high-risk group and to date there has been no consensus with regard to their management. Carotid endarterectomy in these patients is associated with an increased incidence of perioperative myocardial infarction (Biller et

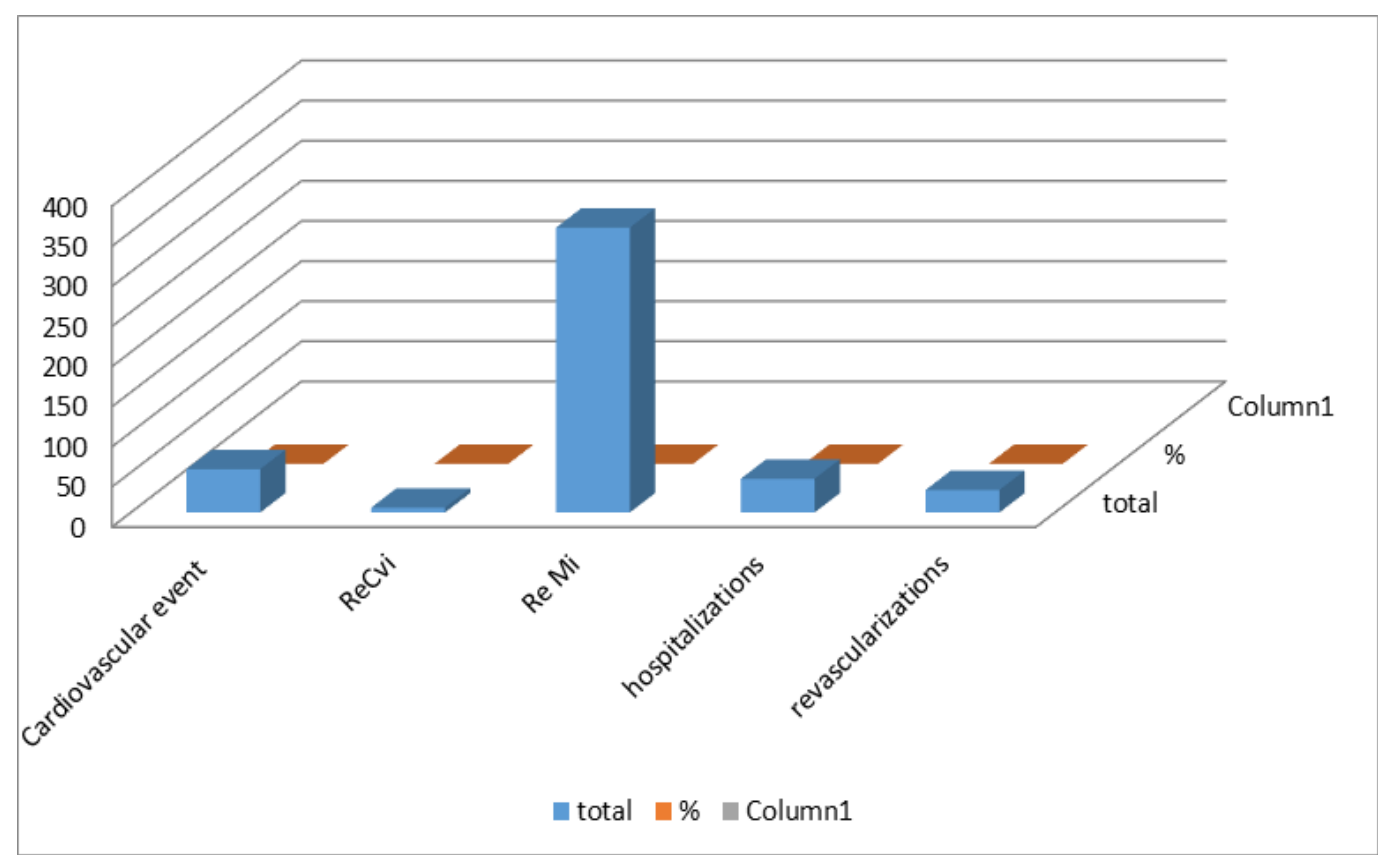

Fig. 1. Cardiovascular events 
Table 3. Correlation of variables with future events in pts with coronary artery disease

Variables in the Equation

\begin{tabular}{|ccc|c|c|c|c|c|c|c|}
\hline & & B & S.E. & Wald & Df & \multirow{2}{*}{ Sig. } & \multirow{2}{*}{ Exp(B) } & \multicolumn{2}{|c|}{$95 \%$ C.I. for EXP (B) } \\
\cline { 7 - 9 } & & & & & & & & Lower & Upper \\
\hline & Obesity & $-, 558)$ & 1,316 &, 180 & 1 &, 671 &, 572 &, 043 & 7,543 \\
& Smoker & $-17,112)$ & 5274,035 &, 000 & 1 &, 997 &, 000 &, 000 &. \\
Step & PAB & $-17,168)$ & 7446,407 &, 000 & 1 &, 998 &, 000 &, 000 &. \\
$1^{\text {a }}$ & DM &, 405 & 1,303 &, 097 & 1 &, 756 & 1,500 &, 117 & 19,272 \\
& stenosis & 1,402 &, 746 & 3,539 & 1 &, 060 & 4,065 &, 943 & 17,525 \\
& Constant & $-4,097)$ &, 919 & 19,889 & 1 &, 000 &, 017 & & \\
\hline
\end{tabular}

Table 4. Relevant data on mortality in patients with Obesity, Smoker, PAB, DM, Carotid stenosis, HTA, HLP for carotid revascularization

\begin{tabular}{|c|c|c|c|c|c|c|c|c|c|}
\hline & \multirow{2}{*}{ B } & \multirow{2}{*}{ S.E. } & \multirow{2}{*}{ Wald } & \multirow{2}{*}{$\mathrm{df}$} & \multirow{2}{*}{ Sig. } & \multirow{2}{*}{$\operatorname{Exp}(B)$} & \multicolumn{2}{|c|}{$\begin{array}{c}95 \% \text { C.I. for } \\
\operatorname{EXP(B)~}\end{array}$} \\
\hline & & & & & & & & Lower & Upper \\
\hline \multirow{8}{*}{$\begin{array}{l}\text { Step } \\
1^{\mathrm{a}}\end{array}$} & Obesity & ,517 & 1,428 &, 131 & 1 & ,717 & 1,678 & , 102 & 27,558 \\
\hline & Smoker & $-17,361)$ & 4684,119 & ,000 & 1 & 997, & ,000 & 000 & . \\
\hline & PAB & $-15,813)$ & 6971,762 & ,000 & 1 & 998 & ,000 & ,000 & . \\
\hline & $\mathrm{DM}$ & 1,278 & 1,466 & ,760 & 1 & ,383 & 3,591 & ,203 & 63,606 \\
\hline & stenosis, & 1,796 & ,972 & 3,414 & 1 & ,065 & 6,027 & 897 & 40,515 \\
\hline & HTA & $-2,416)$ & 1,422 & 2,888 & 1 & ,089 & ,089 & ,005 & 1,449 \\
\hline & HLP & $-17,593)$ & 3882,798 &, 000 & 1 & 996 & ,000 & ,000 & . \\
\hline & Constant & $-2,915)$ & 1,135 & 6,589 & 1 & ,010 & ,054 & & \\
\hline
\end{tabular}

al. 1998), and coronary artery bypass grafting is accompanied by an elevated risk of neurological injury (Jones et al 1984) [11,13].

The present study validated prediction models in a population to identify a cohort of individuals at high risk of carotid stenosis (CS).

Early identification of CS cases allows the initiation or intensification of cardiovascular risk management using triple medical therapy (antithrombotic, antihypertensive, and lipid-lowering medication) to decrease the risk of cardiovascular disease. Carotid intervention might further decrease the risk of stroke in selected cases. Clinical and imaging features associated with an increased risk of stroke in patients with med- ically treated CS, such as silent brain infarction, contralateral stroke, or TIA, plaque echolucency, intraplaque hemorrhage, microemboli, and reduced cerebrovascular reserve, have been identified. Risk stratification tools, using a wide range of predictors, have been developed to estimate long-term stroke and cardiovascular disease risk in cases with CS, but these have not been validated with current medical treatment [14]. Reliable and validated risk stratification tools might help further refine the use of targeted screening for CS by identifying cases at higher risk for stroke and cardiovascular disease [15].

While in a general adult population the prevalence of carotid stenosis approaches $4 \%$ 
(Mathiesen, Joakimsen, et al., 2001), in patients with coronary artery disease it can reach $30 \%-70 \%$ (Kallikazaros et al., 1999; Held et al., 2001; Komorovsky et al., 2004; Lombardo et al., 2004). For those undergoing coronary artery bypass grafting, the prevalence of $>50 \%$ narrowing of at least one internal carotid artery is thought to be around $20 \%$, and $>70 \%$ carotid stenosis is found in $2 \%-12 \%$ of cases (Schwartz et al., 1995; Evangelopoulos et al., 2000).

Carotid artery disease, even in its preclinical stage (intima-media thickness [IMT] $\geq 1 \mathrm{~mm}$ and non-obstructive [ $<50 \%$ ] carotid plaques), has been associated with CAD and an increased risk of cardiovascular events [16].

When treating a patient with significant carotid artery disease, it is important to realize that atherosclerosis is a systemic inflammatory vascular disorder involving multiple arterial beds. These patients are threatened not only for stroke; the presence of carotid artery disease places them into very high-risk group for any of several atherosclerotic cardiovascular (CV) events, especially coronary events. (17) The presence of atherosclerotic disease in more than one arterial system is associated with a higher risk of recurrent symptoms and complications, and patients with detectable disease in the coronary and peripheral arteries are at twice the risk of those presenting with coronary artery disease (CAD) alone [18].

Although modern pharmacotherapy and revascularization techniques have markedly improved the prognosis of patients with atherosclerotic vascular disease, atherosclerosis-related $\mathrm{CV}$ events and cerebrovascular events remain the causes of death in almost $46 \%$ of all cases in developed countries. Detection and treatment of preclinical CAD in patients with significant carotid artery stenosis may improve long-term outcomes and survival, because CAD is the major cause of death not only during follow-up in stroke patients, but also in patients with carotid stenosis.

A relationship between coronary and carotid arterial disease is commonly accepted, confirming that atherosclerosis is a systemic condition. Similar plaque morphology at both vascular sites and predominant plaque location at the branch points of arteries suggest that development of atherosclerotic changes at both sites share similar systemic factors [19]. The prevalence of concomitant atherosclerosis in the carot- id and coronary arteries has been studied under different circumstances, and the proportions vary widely.

Most clinical studies have sought to determine the prevalence of carotid artery atherosclerosis in patients with known CAD. This prevalence differs depending on the study population and is highly dependent on the extent of CAD. Risk factors most commonly associated with carotid stenosis in patients with CAD are extension of CAD, older age, and a history of cerebrovascular disease and concomitant peripheral artery disease.

Patients with carotid artery disease are considered to be at very high risk of $\mathrm{CV}$ events and, according to recognized guidelines on $\mathrm{CV}$ disease prevention, should be treated with statins to a target LDL-cholesterol level of $<1.8 \mathrm{mmol} / \mathrm{L}$ $(20,21)$. Considerable evidence indicates that statin therapy reduces the stroke risk in patients with cerebrovascular disease. In a meta-analysis of randomized trials of statins in combination with other preventative strategies, every 1 $\mathrm{mmol} / \mathrm{L}$ decrease in LDL-C level was associated with a reduction in the relative risk of stroke of $21 \%(P=0.009)[21]$. In terms of the secondary prevention of non-cardioembolic stroke, intensive reduction of the LDL-C level (using statins) significantly prevented both stroke and major CV events $(0.80, \mathrm{P}=0.002)$.

Further investigation of CAD among patients with asymptomatic carotid artery stenosis who are not scheduled for revascularization should depend on the symptoms and should follow appropriate guidelines. However, the situation is different in patients with symptomatic carotid artery stenosis after a recent stroke/transient ischemic event. According to the American Heart Association/American Stroke Association statement, stroke/transient ischemic attack patients should undergo routine noninvasive testing for CAD in the presence of significant carotid disease. Although some studies, including the COURAGE trial, have shown that asymptomatic CAD can be addressed only with optimal medical therapy, the residual risks in studies investigating CV risks in stroke patients with documented asymptomatic $\mathrm{CAD}$ were markedly increased in comparison with those of patients without CAD, despite optimal medical therapy, suggesting that additional interventions may play useful roles. Such interventions could include revascularization in patients after recent stroke with asymp- 
tomatic CAD. However, this remains to be tested [22].

There are numerous risk factors for the development of atherosclerosis and while some directly affect this process, the connection with others is not completely clarified.

The main risk factors are arterial hypertension, lipoproteinemia, diabetes and smoking. The newly discovered risk factors that are being intensively studied are C-reactive protein, lipoprotein (a), fibrinogen, homocysteine, and genetic causes, of each factor separately, is positively correlated with the appearance of CAD [25].

Blood pressure was measured (mean value of 2 readings) with a standard sphygmomanometer in a sitting position. Arterial hypertension was defined as the blood pressure $\geq 140 / 90 \mathrm{mmHg}$ or use of antihypertensive drugs.

It is now known that arterial hypertension (HTA) is the most important risk factor for all subtypes of stroke and hemorrhage, and that its existence increases the probability of stroke by five times, as indicated by a multicenter Framingham study [26].

The results of our study indicate that arterial hypertension was very common regardless of the location of the cerebral infarction. Out of a total of $80(100 \%)$ patients, $64(80 \%)$ had hypertension. In the group of patients with subcortical cerebral infarction, hypertension was present in $33(82.5 \%)$ patients. The group of patients with cortical cerebral infarction had 31 (77.5\%), therefore, slightly fewer patients with registered arterial hypertension.

The analysis of the obtained data shows that arterial hypertension, both systolic and diastolic, is one of the most important risk factors for the development of quantitatively significant arteriosclerosis, which is followed by cerebral infarction, but in the examined groups (0.576).

Arterial hypertension is known to increase the risk of stroke, with a strong association between blood pressure and stroke [27]. With each $10 \mathrm{mmHg}$ increase, the risk of stroke increases by $30 \%$ to $45 \%$. On the other hand, antihypertensive therapy reduces the risk of stroke, as shown in a meta-analysis that included more than 40 studies and more than 188,000 patients; lowering blood pressure by $10 \mathrm{mmHg}$ reduced the risk of stroke by $33 \%$ [28]. Also, antihypertensive therapy reduces the risk of recurrent stroke by $24 \%$ [29]. Taking these facts into account, antihyper- tensive therapy is recommended for all patients who have had an ischemic stroke or TIA [30].

Several epidemiological studies: the ARIC study [31], the Framingham Heart study [32], and the MESA (Multi-Ethnic Study of Atherosclerosis) [33] found a link between the arterial hypertension and the risk of developing carotid atherosclerotic disease.

The SHEP study (Systolic Hypertension in the Elderly Program) found that the systolic blood pressure equal to or greater than 160 $\mathrm{mmHg}$ was one of the most important independent predictors of carotid stenosis [34]. Also, the PROGRESS study (Preventing Strokes by Lowering Blood Pressure in Patients with Cerebral Ischemia) showed that the treatment with ACE inhibitors and diuretics significantly reduces the risk of recurrent stroke [35].

A very interesting question arises as to whether antihypertensive therapy is useful or leads to additional ischemia due to decreased cerebral perfusion in symptomatic patients with significant carotid artery stenosis. On the other hand, if arterial hypertension lasts long enough, it can lead to changes in small blood vessels, leading to changes in brain mass that are described on magnetic resonance imaging as white mass "hyperintensities". These white mass hyperintensities are crucial because they are associated with poorer response to treatment, consequent cognitive impairment, as well as an increased rate of deterioration and progression to chronic forms of depression.

Diabetes mellitus - the risk of ischemic stroke in patients with diabetes mellitus (DM) is increased 2-5 times compared with patients who do not have diabetes [36]. Similar has been reported in various studies; the results of the IRAS (Insulin Resistance Atherosclerosis Study) study [37] showed significantly faster progression of intima medial thickening and the occurrence of heart and brain infarction.

The EDIC (Epidemiology of Diabetes Interventions and Complications) study, in addition to the same finding as in the previous one, found that the progression of atherosclerotic lesions in the carotid arteries was slower in patients treated with invasive insulin therapy than in patients treated conventionally [38].

Evidence has been obtained in most European and North American countries that diabetes is a risk factor for all types of cerebrovascular 
disease, but especially subcortical infarction when associated with hypertension [39].

A large number of statistical studies by our and world authors show a higher number of diabetics among patients with manifestations of ischemic brain disease, which ranges from $18 \%$ to $43 \%$, while the percentage of this disease in the general population is around $6 \%$.

In our study, DM (27.8\%) patients had DM as a risk factor for carotid stenosis. The results of the study coincide with a number of studies that support the view that DM is an important risk factor for cerebral infarction.

Interestingly, in Fischer's initial work, only $11 \%$ of his subjects with subcortical infarction suffered from diabetes, so he felt that cerebrovascular disease was not associated with diabetes.

Contrary to this opinion, the already mentioned study indicates a significant prevalence of diabetes in $34 \%$ of cases and that, in fact, it is an important risk factor for the occurrence of infarction, especially subcortical localization.

Hyperlipoproteinemia (HLP) is the most responsible for the accelerated process of atherosclerosis. HLP occurs due to disorders of lipid transmission due to accelerated synthesis or slowed degradation of lipoproteins, particles that carry cholesterol or triglycerides in plasma.

HLP as an important risk factor was present in one third of $29(36.2 \%)$ of our patients regardless of the type of infarction lesion. In the group with subcortical infarction, it was present in 15 $(37.5 \%)$ patients, while in the group with cortical infarction, hyperlipoproteinemia was present in $14(35.0 \%)$ patients. There was no statistical significance between the examined groups $(\mathrm{p}=$ 0.816).

Hyperlipidemia is generally known as the main risk factor for arteriosclerosis, with the main emphasis on hypercholesterolemia and low-density lipoprotein (LDL), while high-density lipoprotein (HDL) enables the elimination of cholesterol from the cell. Today, it is clear that dyslipidemia is an important risk factor for cerebrovascular disease, especially ischemic stroke, and that the administration of drugs for dyslipidemia, especially statins, with appropriate treatment of arterial hypertension, diabetes, smoking cessation and weight maintenance, is key in secondary ischemic prevention of stroke [40].
This research is also confirmed by the European guidelines for the prevention of cardiovascular diseases, which were jointly developed by ten relevant European societies, including the European Stroke Initiative [41].

Epidemiological studies show a strong association between cholesterol and carotid artery atherosclerosis determined by measuring the thickness of the intima-medial complex. The Framingham Heart study showed that the relative risk of carotid stenosis $>25 \%$ is about 1.1 for each increase in total cholesterol by $10-\mathrm{mg}$ / dL [42]. However, statin therapy significantly reduces the risk of stroke in patients with atherosclerosis [43], as shown in several meta-analyzes $[122,126]$. Statin therapy reduces the absolute risk of stroke over 5 years by $2.2 \%$ and the relative risk of all stroke by $16 \%$ [44].

Almost all large, randomized, double-blind, and placebo-controlled clinical trials with statins, based on results published in the last fifteen years, have clearly shown that statins can prevent or reduce non hemorrhagic strokes, is stroke and mortality.

Analysis of the database from the Johans Hopkins Hospital for Cardiac Surgery, in which all patients were followed prospectively, provided very informative evidence related to the occurrence of stroke in this milieu [45]. A total of $74 \%$ of patients had a stroke on the day of the operation and $91 \%$ within the first 3 days after surgery, which speaks in favor of the fact that the stroke is directly related to the operative procedure. Stroke in this group was found in 214 patients $(3.6 \%)$, and neuroimaging findings showed acute infarction in $72 \%$. As many as a quarter of these strokes were in the border cortical fields of the middle cerebral artery. Survival of stroke patients in this study was $67 \%$ in the first and $47 \%$ after 5 years, which is less than in the stroke group of the second etiology. In addition, the results of a study by Lee and co-workers clearly established the understanding that severe systemic hypotension associated with significant carotid stenosis can cause not only unilateral but also bilateral infarctions in the border cortical zones of the cerebral media artery [46].

Bad life habits and association of risk factors - When looking at risk factors for ischemic brain disease or arteriosclerosis, smoking, alcohol consumption, obesity and physical inactivity are classified as bad habits, but they are also risk factors that can be influenced. The obtained data agree 
with the data from the literature on the harmful effects of cigarette smoking on the development and progression of atherosclerosis. First of all, the results of the Framingham study, which included 4,255 male and female respondents, aged 36 to 68 , who were followed for 26 years, indicate that smoking significantly contributes to the occurrence of stroke, and that the risk of stroke increases with the number of daily smoked cigarettes.

Progression of atherosclerosis of the carotid arteries was found not only in active smokers but progression of atherosclerotic changes of the carotid arteries was also found in non-smokers who were exposed to passive smoking [47].

Similar results were published in the Cardiovascular Health Study; the degree of carotid artery stenosis was higher in current than in former smokers, with a significant correlation between the degree of stenosis and the number of cigarettes smoked per day and years of smoking [48]. The obtained results speak in favor of the fact that the effect of smoking is reversible and should be an incentive for smokers to stop this bad habit.

In the recent years, the connection between obesity and neurological diseases has been increasingly researched. Obesity is recognized as a clear risk factor for cardiovascular disease, however, the link between obesity and stroke is still not completely clear. A published guide by the Stroke Council of the American Heart Association characterizes obesity as a potential risk factor for stroke that can be influenced [49].

In our study, obesity was slightly more common in the group of patients with subcortical $20(50 \%)$ than in the group of patients with cortical cerebral infarction 14 (35\%).

The influence of arrogance on arteriosclerosis is indirect. The dominant position is a disproportionately large influence on the development of DM by increasing insulin resistance, which is almost proportional to the patient's body weight. This is understandable because obesity directly affects risk factors for cerebrovascular diseases primarily hypertension, elevated cholesterol levels and glucose intolerance.

Research conducted in recent years has shown that heredity plays a significant role in the etiology of cerebrovascular diseases, and that many risk factors for stroke are genetically determined [50].
Several studies have shown a clear role for genetic factors for all types of cerebrovascular disease, both ischemic and hemorrhagic [51].

Studies that have tried to bring the answer to the question of whether stroke is a genetic disease in itself have yielded controversial results. The analysis of our results shows that more patients with a positive family history were in the group with subcortical cerebral infarction 24 $(60 \%)$ than in the group of patients with cortical cerebral infarction 17 (42.5\%).

By analyzing the data from the inevitable Framingham study, a general risk profile for cerebrovascular diseases was defined, with the help of which it is possible to single out those $10 \%$ of the members of the population who will later develop a stroke. This profile consists of five risk factors: elevated systolic blood pressure, elevated serum cholesterol, glucose intolerance, smoking, and electrocardiographically proven left ventricular hypertrophy $[52,53]$.

This finding is important because according to data from the Framingham study, in patients who did not have any or had one of the valid risk factors, the risk of getting a stroke in five years is $22 \%$, compared to the risk of $42 \%$ had individuals with three or four pronounced risk factors.

\section{CONCLUSION}

This original paper indicates that carotid stenosis is predictive factor for future cardiovascular events in coronary artery disease population including death.

Screening for carotid artery disease by ultrasound is a crucial to detect symptom-free diseases that can cause unexpected disability or morbidity. When assessing the balance between benefits and harms of screening, identifying the factors associated with an increased risk of the disease are more important. We showed that diabetes and obesity were also significant risk factors for prognosis of this population. These findings might contribute to future studies to assess the benefits and cost-effectiveness of population screening for carotid atherosclerosis. 


\section{REFERENCES}

1. LGeorge J, Rapsomaniki E, Pujades-Rodriguez M, Shah AD, Denaxas S, Herrett E, Smeeth L, Timmis A, Hemingway H. How does cardiovascular disease first present in women and men?Circulation. 2015; 132: 1320-1328.

2. Goessens BM, Visseren FL, Kappelle LJ, Algra A, van der Graaf Y. Asymptomatic carotid artery stenosis and the risk of new vascular events in patients with manifest arterial disease: the SMART study. Stroke. 2007; 38: 1470-1475.

3. M. Bosevski, L. Stojanovska, Progression of carotid-artery disease in type 2 diabetic patients: a cohort prospective study, Vascular health and risk management 2015; 11: 549.

4. Bosevski M., Borozanov V., Vavlukis M., Pemovska G.,Georgievska-Ismail Lj., Carotid ultrasound, blood lipids, and waist determination can predict future revascularization in the type 2 diabetic cohort. Prilozi. Odd. biol. med. nauki, MANU, XXVIII, 2, Contributions, Sec. Biol. Med. Sci., 2007; 616.379-008.64.

5. M Bosevski, G Bosevska, L Stojanovska, Influence of fibrinogen and C-RP on progression of peripheral arterial disease in type 2 diabetes: a preliminary report Cardiovascular diabetology $12(1), 1-6$.

6. M Bosevski, S Kostoska, S Tosev, V Borozanov, Usefulness of D-Dimers and fibrinogen plasma determination in patients with polyvascular disease Angiologiia i sosudistaia khirurgiia $=$ Angiology and vascular surgery 2006; 12:2: 9-15.

7. M Bosevski, I Peovska, Clinical Usefulness of Assessment of Ankle-Brachial Index and Carotid Stenosis in Type 2 Diabetic PopulationThree-Year Cohort Follow-Up of Mortalit,Angiology 64 (1), 64-68.

8. de Weerd M, Greving JP, Hedblad B, Lorenz MW, Mathiesen EB, O'Leary DH, Rosvall M, Sitzer M, Buskens E, Bots ML. Prevalence of asymptomatic carotid artery stenosis in the general population: an individual participant data metaanalysis. Stroke. 2010; 41: 1294-1297.

9. Ricotta JJ, Aburahma A, Ascher E, Eskandari M, Faries P, Lal BK; Society for Vascular Surgery. Updated Society for Vascular Surgery guidelines for management of extracranial carotid disease. J Vasc Surg. 2011.

10. Adams M, Nakagomi A, Keech A, et al. Carotid intima-media thickness is only weekly correlated with the extent and severity of coronary artery disease. Circulation. 1995; 92: 2127-34.

11. Crouse JR, III, Tang R, Espeland MA, et al. Associations of extracranial carotid atherosclerosis progression with coronary status and risk factors in patients with and without coronary artery disease. Circulation. 2002; 106: 2061-6.

12. Grant EG, Benson CB, Moneta GL, et al. Carotid artery stenosis: gray-scale and Doppler US diagnosis - Society of Radiologists in Ultrasound Consensus Conference. Radiology. 2003; 229: 340.

13. Joakimsen O, Bønaa KH, Mathiesen EB, et al. Prediction of mortality by ultrasound screening of a general population for carotid stenosis. The Tromsø Study. Stroke. 2000; 31: 1871-6.

14. Jones E, Craver J, Michalic R, et al. Combined carotid and coronary artery operations: when are they necessary? J Thorac Cardiovasc Surg. 1984; 87: 7-16.

15. A. Steinvil, B. Sadeh, Y. Arbel, et al.Prevalence and predictors of concomitant carotid and coronary artery atherosclerotic disease J Am Coll Cardiol, 57 (2011), pp. 779-783.

16. V. Aboyans, P. Lacroix, Indications for carotid screening in patients with coronary artery disease, Presse Med, 38 (2009), pp. 977-986.

17. Komorovsky R, Desideri A, Coscarelli S, et al. Impact of carotid arterial narrowing on outcomes of patients with acute coronary syndromes. Am J Cardiol. 2004; 93: 1552-5.

18. Komorovsky R, Desideri A, Coscarelli S, et al. Predictive value of associations between carotid and coronary artery disease in patients with acute coronary syndromes. Am J Cardiol. 2005; 95: 116-19. [PubMed] [Google Scholar].

19. Nicolaides AN, Kakkos SK, Kyriacou E, Griffin M, Sabetai M, Thomas DJ, Tegos T, Geroulakos G, Labropoulos N, Dore CJ, et al. Asymptomatic internal carotid artery stenosis and cerebrovascular risk stratification. J Vasc Surg. 2010; 52: 1486-1496.

20. Marquardt L, Geraghty OC, Mehta Z, Rothwell PM. Low risk of ipsilateral stroke in patients with asymptomatic carotid stenosis on best medical treatment: a prospective, population-based study. Stroke. 2010; 41: e11-e17.

21. Schmidt C, Fagerberg B, Wirkstand J, et al. RIS Study Group Multiple risk factor intervention reduces cardiovascular risk in hypertensive patients with echolucent plaques in the carotid artery. J Intern Med. 2003; 253: 430-8. [PubMed] [Google Scholar].

22. Schwartz LB, Bridgman AH, Kieffer RW, et al. Asymptomatic carotid artery stenosis and stroke in patients undergoing cardiopulmonary bypass. J Vasc Surg. 1995; 21: 359-64.

23. Arnett DK, Tyroler HA, Burke G, Hutchinson R, Howard G, Heiss G: Hypertension and subclinical carotid artery atherosc1erosis in blacks and whites. The Atherosc1erosis Risk in Communities Study. ARIC Investigators, Arch Intern Med, 1996; 156 (17): 1983-1989. 
24. Bacha J, Aboud E, Courreges JP : Prevalence and aspects of arteriopathies in non insulin- dependent diabetes mellitus with severe hypertension, Arch Mal Coeur Vaiss, 1997; 90(8): 1065-1069.

25. Briel M, Studer M, Glass TR, et al. Effects of statins on stroke prevention in patients with and without coronary heart disease: a meta- analysis of randomized controlled trials. Am J Med. 2004; 117: 596-606.

26. [ECPS] European Carotid Plaque Study Group. Carotid artery plaque composition - relationship to clinical presentation and ultrasound B-mode imaging. Eur J Vasc Endovasc Surg. 1995; 10: 23-30.

27. Furie KL, Kasner SE, Adams RJ, et al. Guidelines for the prevention of stroke in patients with stroke or transient ischemic attack: a guideline for healthcare professionals from the American Heart Association/American Stroke Association. Stroke. 2011; 42: 227-276.

28. Goes E, Janssens W, Maillet B, et al. Tissue characterization of atheromatous plaques. Correlation between ultrasound image and histological findings. J Clin Ultrasound. 1990; 18: 611-17. [PubMed] [Google Scholar].

29. Gray-Weale AC, Graham JC, Burnett JR, et al. Carotid artery atheroma: comparison of preoperative B-mode ultrasound appearance with carotid endarterectomy specimen pathology. J Cardiovasc Surg. 1988; 29: 676-81. [PubMed] [Google Scholar].

30. P. Amarenco, P.C. Lavallée, J. Labreuche, et al. Prevalence of coronary atherosclerosis in patients with cerebral infarction,Stroke, 42 (2011), pp. 22-29.

31. Task Force Members, G. Montalescot, U. Sechtem, S. Achenbach, F. Andreotti, et al. 2013 ESC guidelines on the management of stable coronary artery disease: the Task Force on the management of stable coronary artery disease of the European Society of Cardiology European Heart Journal, 34 (2013), pp. 2949-3003.

32. Rodgers A, MacMahon S, Gamble G, et al. Blood pressure and risk of stroke in patients with cerebrovascular disease: the United Kingdom Transient Ischaemic Attack Collaborative Group. BMJ. 1996; 313: 147.

33. Neal B, MacMahon S, Chapman N, Blood Pressure Lowering Treatment Trialists' Collaboration.Effects of ACE inhibitors, calcium antagonists, and other blood-pressure- lowering drugs: results of prospectively designed overviews of randomised trials. Lancet. 2000; 356: 1955-64.

34. Rashid P, Leonardi-Bee J, Bath P. Blood pressure reduction and secondary prevention of stroke and other vascular events: a systematic review. Stroke. 2003; 34: 2741-8.
35. Rothwell PM, Eliasziw M, Gutnikov SA, et al. Endarterectomy for symptomatic carotid stenosis in relation to clinical subgroups and timing of surgery. Lancet. 2004; 363: 915-24.

36. Howard G, Manolio TA, Burke GL, et al, The Atherosclerosis Risk in Communities (ARIC) and Cardiovascular Health Study (CHS) Investigators. Does the association of risk factors and atherosclerosis change with age? An analysis of the combined ARIC and CHS cohorts. Stroke.

37. Wilson PW, Hoeg JM, D'Agostino RB, et al. Cumulative effects of high cholesterol levels, high blood pressure, and cigarette smoking on carotid stenosis. N Engl J Med. 1997; 337: 516 -22.1997; 28: 1693-701.

38. Psaty BM, Arnold AM, Olson J, et al. Association between levels of blood pressure and measures of subclinical disease multiethnic study of atherosclerosis. Am J Hypertens. 2006; 19: 1110 -7 .

39. Sutton-Tyrrell K, Alcorn HG, Wolfson SK Jr, et al. Predictors of carotid stenosis in older adults with and without isolated systolic hypertension. Stroke. 1993; 24: 355- 61.

40. PROGRESS Collaborative Group. Randomised trial of a perindopril-based blood- pressurelowering regimen among 6,105 individuals with previous stroke or transient ischaemic attack. Lancet. 2001; 358: 103.

41. Karapanayiotides T, Piechowski-Jozwiak B, van Melle G, et al. Stroke patterns, etiology, and prognosis in patients with diabetes mellitus. Neurology. 2004; 62: 1558-62.

42. Haffner SM, Agostino RD Jr, Saad MF, et al. Carotid artery atheroscle- rosis in type- 2 diabetic and nondiabetic subjects with and without symptomatic coronary artery disease (The Insulin Resistance Athero- sclerosis Study). Am J Cardiol. 2000; 85: 1395-400.

43. Nathan DM, Lachin J, Cleary P, et al. Intensive diabetes therapy and carotid intima- media thickness in type 1 diabetes mellitus. N Engl J Med. 2003; 348: 2294-303.

44. Kadoglou NP, Avgerinos ED, Liapis CD.: An update on markers of carotid atherosclerosis in patients with Type 2 diabetes. Biomark Med. 2010 Aug; 4(4): 601-9.

45. Baigent C, Keech A, Kearney PM, et al. Efficacy and safety of cholesterol-lowering treatment: prospective meta-analysis of data from 90,056 participants in 14 randomised trials of statins. Lancet. 2005; 366: 1267-78.

46. Heart Protection Study Collaborative Group. MRC/ BHF Heart Protection Study of cholesterol-lowering with simvastatin in 20.536 high-risk individuals: a randomised placebo-controlled trial. Lancet 2002; 360: 7-22. 
47. Briel M, Studer M, Glass TR, et al. Effects of statins on stroke prevention in patients with and without coronary heart disease: a meta-analysis of randomized controlled trials. Am J Med. 2004; 117: 596-606.

48. Amarenco P, Labreuche J, Lavallee $\mathrm{P}$, et al. Statins in stroke prevention and carotidatherosclerosis: systematic review and up-to-date meta-anal- ysis. Stroke. 2004; 35: 2902-9.

49. Josephson SA, Bryant SO, Mak HK, et al. Evaluation of carotid stenosis using CT angiography in the initial evaluation of stroke and TIA. Neurology. 2004; 63: 457-60.
50. O'Regan C, Wu P, ArovrP, Perri 0, Mills EJ. Statin therapy in stroke prevention: a meta- analysis involving 121,000 patients. AmJ Med 2008; 121: 24-33.

51. Živković M, Šternić N, Kostić VS. Ishemična bolest mozga. Zavod za udžbenike i nastavna sredstva, Beograd, 2000.

52. Salazar JD, Wityk RJ, Grega, MA, Borowicz LM, Doty JR, Petrofski JA, Baumgartner WA. Stroke After Cardiac Surgery: Short- and Long-Term Outcomes. Ann Thorac Surg 2001; 72: 1195-202.

53. Bosevski M. Carotid artery disease in diabetic patients. Pril (Makedon Akad Nauk Umet Odd Med Nauki). 2014; 35(3): 149-61.

\title{
Резиме
}

\section{УЛОГАТА НА КАРОТИДНАТА СТЕНОЗА ВО ПРЕТСКАЖУВАЊЕТО НА ПРОГНОЗАТА НА КОРОНАРНАТА АРТЕРИСКА БОЛЕСТ}

\author{
Саветка Паљошковска Јорданова ${ }^{1}$, Сашко Кедев ${ }^{1}$, \\ Даница Петковска Спирова ${ }^{1}$, Лили Стојановска ${ }^{2}$, Маријан Бошевски ${ }^{1}$
}

\footnotetext{
${ }^{1}$ Универзитетска Клиника за кардиологија, Медицински факултет Скопје, РС Македонија

${ }^{2}$ Колеџ за Медицински и здравствени науки, Ал Аим, Обединети Арапски Емирати
}

Цели: Целта на овој труд е да се покаже дали каротидната стеноза е предвидлива за прогнозата на коронарна артериска болест.

Метод и материјали: Нашата студија е проспективна кохортна студија. Консекутивно беше собран 1031 пациент со докажана коронарна артериска болест (КАБ). Каротидниот ултразвук беше применет за процена на ИМТ, плака или стеноза. За 24 месеци беа следени за кардиоваскуларни збиднувања. Одбрани демографски податоци (историја на пушење, дислипидемија, хипертензија, лабораториски вредности и клинички податоци (придружни болести и ризик) се собираат од секој пациент. Вкупните кардиоваскуларни настани и морталитет беа резултат на испитаната популација. Резултатите беа собрани потенцијално и ретроспективно. Студијата беше организирана како клиничка, пресечна студија и компаративна студија.

Од податоците собрани од клиничкото истражување, во статистичката програма беше формирана датотека со чија помош статистички беа анализирани податоците.

Од методите на описна статистика, се користеа апсолутни фреквенции, проценти, аритметичка средина, медијана, мерки на варијабилност, минимална, максимална, стандардна девијација. Логистични модели беа користени за пределување на предиктори на прогноза

Тестирањето на значењето е извршено на ниво на веројатност $\mathrm{p}<0,05$, што е потребно и доволно во медицинската научноистражувачка работа за да се извлечат релевантни заклучоци.

Резултат: Од вкупниот број пациенти, 1026 имале артериска хипертензија (XТА). Податоци за хиперлипидемија (ХЛП) се пријавени кај 895 пациенти. 1023 пациенти имале периферна артериска болест (ПАБ). На 1031 пациент му беше презентирана мултицеселна коронарна артериска болест (КАБ). Имаше 1.029 пациенти со дијабетес мелитус (ДМ), додека 1013 пациенти имаа коронарен артериски бајпас (КАБП), а 1012 имаа исхемичен мозочен удар (ИМУ). Зголемен систолен крвен притисок е пријавен кај 966 пациенти. 184 пациенти имале покачени триглицериди и 187 покачен холестерол. $\mathrm{HgA1C}$ беше покачен кај 144 пациенти. 1008 пациенти имале миокарден инфаркт. Каротидната артерија стеноза (КАС) е пронајдена кај 1009 пациенти.

1031 пациент бил следен 24 месеци. Кардиоваскуларни настани или 5,2 \% се пријавени 
кај 54 пациенти. Реваскуларизација е извршена кај 28 (4,1 \%) пациенти, додека 12 (1,8 \%) од пациентите починале. Утврдено е дека дијабетес мелитус (ОР 1.878 95\% CI 0,491 7,184) и каротидна стеноза (ОР 2,185 95 \% ЦИ 0,731 6,53) се претскажувачки фактори за идните кардиоваскуларни настани.

Заклучок: Како резултат на нашите резултати, каротидниот ултразвук може да биде корисна алатка за стратификација на ризикот од корорнарна артериска болест.

Клучни зборови: каротидна стеноза, коронарна артериска болест, прогноза 